\title{
Effects of Municipal Reclaimed Wastewater Irrigation on Organic and Inorganic Composition of Soil and Groundwater in Souhil Wadi Area (Nabeul, Tunisia)
}

\author{
Jemai $\mathrm{I}^{1 *}$, Ben Aissa $\mathrm{N}^{2}$, Gallali $\mathrm{T}^{1}$ and Chenini $\mathrm{F}^{3}$
}

${ }^{1}$ Faculté des sciences de Tunis (FST) Campus Universitaire - Tunis - 1060 Tunisie

${ }^{2}$ Institut national d'agronomie de Tunisie (INAT). 43, avenue Charles Nicolle 1082-Tunis Mahrajène Tunisie

${ }^{3}$ Institut national de Recherche en Génie Rural Eaux et Forêt (INFGREF). Avenue El Hadi Karray 2049 Ariana Tunisie

\begin{abstract}
Tunisia has mobilized the important amount of its conventional hydraulic resources (surface water and ground water). It is brought today, for considerations of saving of water but also in environmental ethics, to recycle its noconventional resources like municipal waste water and to applicant it for agriculture. The effect of treated wastewater (TWW), compared to the ordinary irrigation (with ground water (GW)) by means of tow irrigation methods (sprinkler (S) and integrated Gouttor (IG)) on the chemical properties of the sandy soil, and its organic composition, were investigated in 2004 at the experimental station of Oued-Souhil in Nabeul Governorate, NE Tunisia. Soil samples were collected from five depths $(0-20,20-40,40-60,60-80$ and $80-100 \mathrm{~cm})$ and were analyzed for electric conductivity $(E C), p H$, total nitrogen (TN), organic carbon $(\mathrm{OC})$, potassium $(\mathrm{K})$, phosphorus $\left(\mathrm{P}_{2} \mathrm{O}_{5}\right)$ and nitrate $\left(\mathrm{NO}_{3}^{-}\right)$.

The results observed after a partner of irrigation show that the electric conductivity (EC) and $\mathrm{pH}$ of experimental soil decreased compared to his initial state. The irrigation has reduced the $\mathrm{OC}$ content in surface layer and has increased it in the deeper layer. The TN content varied in opposite direction. The $\mathrm{P}_{2} \mathrm{O}_{5}, \mathrm{~K}$ and $\mathrm{NO}_{3}{ }^{-}$concentrations decreased in the upper $40 \mathrm{~cm}$ at the end of the study for both TWW and GW irrigated soil; however the effect of TWW irrigation was significant only with potassium $(\mathrm{K})$. The evolution of these elements in the soil during the study proves their important concentration in the GW.
\end{abstract}

Keywords: Sandy soil, Treated waste water, Nitrate, Phosphorus, Irrigation, Groundwater

\section{Introduction}

In recent years, many Mediterranean countries have experienced severe water supply and demand imbalances, with more frequent and longer periods of drought. In Tunisia, several regions have suffered successive droughts over the last 10 years [1]. Due to water scarcity and population growth, the demand on freshwater increases and agricultural activities (using more than $80 \%$ of the total water resource extracted) are in competition with other demands (domestic and industrial). A national wastewater reuse policy was launched at the beginning of the eighties in Tunisia. The first wastewater reuse regulation was issued in 1989. The reclaimed water has been used mainly for irrigation $(9000$ ha in 2005), the reuse of TWW is currently an integral part of national water resources strategy [2-4]. $29 \%$ of treated sewages are reused for the cultivation of fruit trees, cereals, fodder crops and industrial crops (7900 ha of agricultural lands in 2005) as well as for golf courses (760 ha in 2005) and green spaces (340 ha in 2005). TWW is also reuse in recharges purposes and conservation of wetlands. It is actually considered as an additional water resource and as a potential source of fertilizing elements [5].

The reuse of treated domestic wastewater in agricultural purposes has been increasingly considered to be beneficial for crop production, and due to its significant source of nutrients for the plants $[6,7]$ it can help to reduce the requirements for commercial fertilizers [8]. First and foremost, it is promoted in order to save fresh water for water supply and to protect receiving waters.

However, under certain conditions, this type of water if not well managed, can have negative impacts on cultivated crops and soils, particularly on soil salinity and sodicity, so that the effluent for reuse must comply with reuse standards to minimize environmental and health risks [9]. Among the potential risks associated with TWW irrigation are degradation of soil structure, decrease in soil hydraulic conductivity $[10,11]$, surface sealing, runoff and soil erosion problems, soil compaction, soil contamination with faecal coliform [12,13] and pollution of groundwater, as a result of high nitrogen concentration [14]. Generally, as stated in the 2002 Hyderabad Declaration, on Wastewater Use in Agriculture, 'without proper management, wastewater use poses serious risks to human health and the environment', [15]. However, environmental risks to the soil compartment have been much less studied, with the exception of heavy metals [8,16-21].

The choice of irrigation method can also influence the soil chemical response to TWW irrigation. Studies about changes in the chemical properties of soils irrigated with TWW have mainly shown an increase of $\mathrm{Na}^{+}$and a fast oxidation of $\mathrm{NH}_{4}^{+}$into $\mathrm{NO}_{3}^{-}$using subsurface dripping [22] or sprinkling aspersion $[23,24]$.

The experimental station of Oued-Souhil in Nabeul constitutes since the eighties a pilot site for the management and the control of the reuse of the treated municipal waste water. Most studies focus

*Corresponding author: Jemai I, Faculté des sciences de Tunis (FST) Campus Universitaire - Tunis - 1060 Tunisie, Tel: 0021698959954; E-mail: j_amona20@yahoo.fr

Received May 28, 2013; Accepted November 28, 2013; Published December 03, 2013

Citation: Jemai I, Ben Aissa N, Gallali T, Chenini F (2013) Effects of Municipal Reclaimed Wastewater Irrigation on Organic and Inorganic Composition of Soil and Groundwater in Souhil Wadi Area (Nabeul, Tunisia). Hydrol Current Res 4: 160 doi:10.4172/2157-7587.1000160

Copyright: (c) 2013 Jemai I, et al. This is an open-access article distributed under the terms of the Creative Commons Attribution License, which permits unrestricted use, distribution, and reproduction in any medium, provided the original author and source are credited. 
on yield crop under irrigation and nitrogen fertilization or on health risks [25]. However, impact of the irrigation by TWW, especially in an experiment field, on evolution of chemical elements in the soil is not well studied yet. The goal of this study is to evaluate, on short period, the effects of the TWW irrigation, in comparison to that of the GW, on the inorganic and organic composition of a soil cultivated with potato and never irrigated by TWW.

\section{Materials and Methods}

\section{Site description}

This study was conducted during October-March 2004, at the experimental station of Souhil Wadi $\left(36^{\circ} 27^{\prime} 22^{\prime \prime} \mathrm{N} 10^{\circ} 42^{\prime} 02^{\prime \prime}\right.$ E, Figure 1) near Nabeul city which is located at 'Cap Bon' peninsula at the North Eastern part of Tunisia. The altitude is $25 \mathrm{~m}$ above mean sea level. The site is characterized by a Mediterranean semi-arid climate (rainy and fresh winter without frosts) with a mean annual precipitation of 391 $\mathrm{mm}$ concentrated during the months of September to December and a mean annual temperature of $18,3^{\circ} \mathrm{C}$.

The station comprises a reclaimed water irrigated plots and an artificial recharge site. The effluents of two sewage treatment plants, SE3 (oxidation ditches) and SE4 (activated sludge) are stored in a 4500 $\mathrm{m}^{3}$ capacity storage basin.

During the summer season, effluents are carried in a network to provide irrigated subunits where mainly citrus trees and fodder are grown. During the fall season the effluents are used for artificial aquifer recharge by spreading on infiltration basins.

As for the groundwater, the Hammamet-Nabeul aquifer is the main water resource in the station. The vadose zone of the aquifer has been described by Rekaya [26] and Plata Bedmar and Rekaya [27] and more recently by Kallali and Yoshida [28] as varying between 10 and $13 \mathrm{~m}$ thick from the river bed to the infiltration basins. The aquifer is about 2-3 $\mathrm{m}$ thick; the substratum is formed of Pliocene clay with $12 \mathrm{~m}$ thickness at the level of the recharge site.

At the level of the irrigated area, the groundwater table is estimated to be about $10 \mathrm{~m}$ deep [29]. This was confirmed by measures done between June 2004 and April 2006 in the monitoring wells in the recharge site. The permeability of the aquifer is estimated between $10^{-5}$ and $6.10^{-3} \mathrm{~m} / \mathrm{s}$.

The soil of experimental field is composed of alluvia of coarse material belonging to the Quaternary marine formation and is classified as Vertic Xero Fluvent according to American classification. The texture is sandy with low contents of silts and clays, and the surface infiltration rate at saturation level is $4.310^{-3} \mathrm{~ms}^{-1}$. The physical characteristics of this soil at the beginning of the study are listed in Table 1.

\section{Experimental design}

The field experiment was carried out on $750 \mathrm{~m}^{2}$ plots which are divided in two blocs adopted as two main treatments: GW treatment corresponding to irrigation with groundwater and TWW treatment corresponding to irrigation with treated waste water. In each treatment, the irrigation by sprinkler (S) and integrated Gouttor (IG) was repeated in three blocs respectively in a manner that GW and TWW blocs are divided in six (3 S and $3 \mathrm{IG}$ ). The GW was pumped from the wells of surface of the station. The TWW were from the wastewater treatment plant of Dar Châabane (SE4) with a mainly urban wastewater origin $9585 \mathrm{~m}^{3} /$ day [30].

A crop of potato (SPUNTA variety) was sown on October 10,

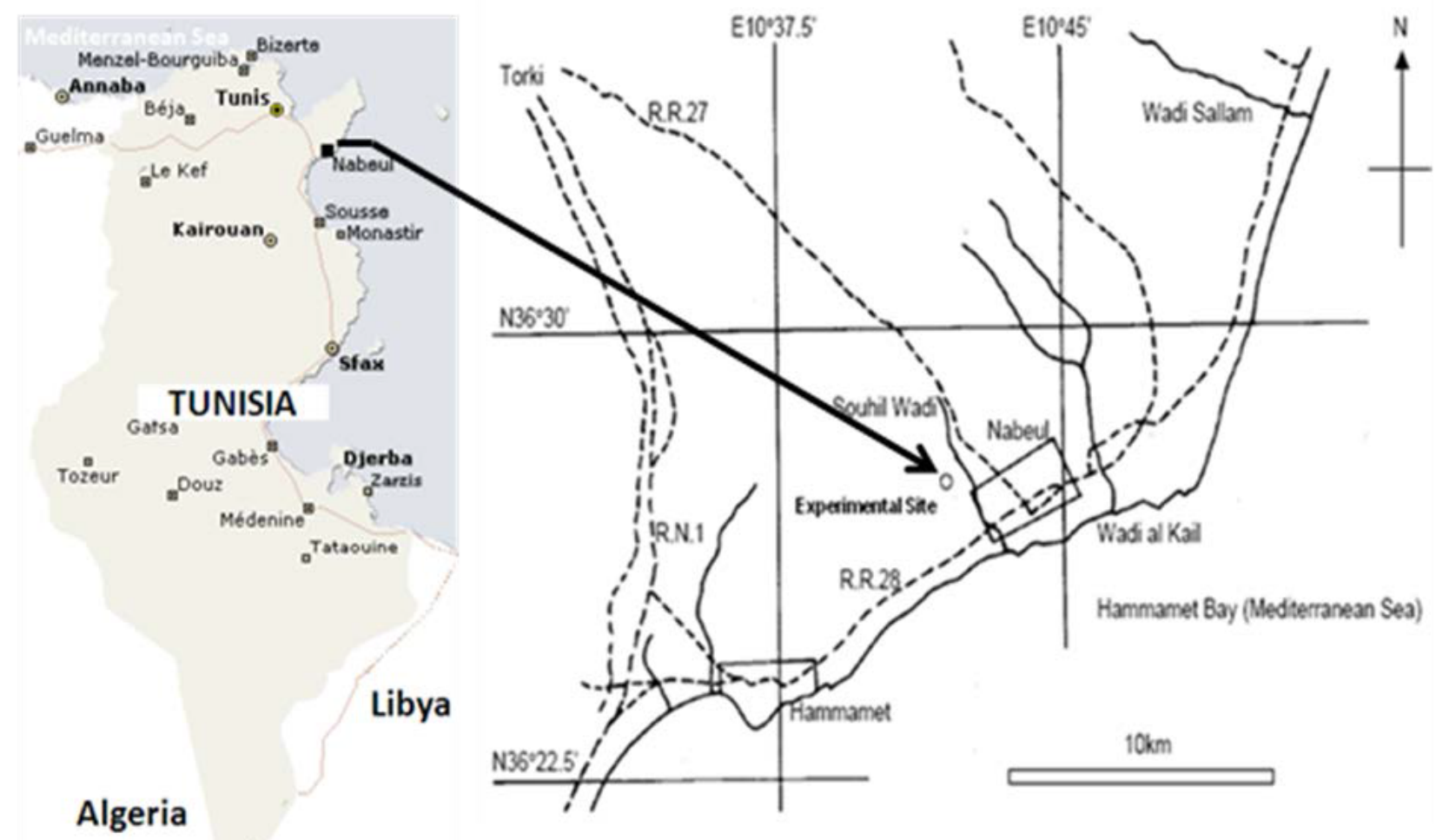

Figure 1: Location map of the experimental site. 


\begin{tabular}{|c|c|c|c|c|c|c|c|c|c|}
\hline Depth $(\mathrm{cm})$ & Clay (\%) & Loam (\%) & Sand (\%) & $\mathrm{pH}$ & $\mathrm{EC}(\mathrm{mS} / \mathrm{cm})$ & $\mathrm{CaCO}_{3}(\%)$ & $\mathrm{C} \%$ & $\mathrm{~N} \%$ & $\mathrm{C} / \mathrm{N}$ \\
\hline $0-20$ & 7.4 & 3.20 & 88.20 & 8.7 & 0.90 & 4.6 & 2.14 & 0.038 & 56.3 \\
\hline $20-40$ & 10.4 & 4.80 & 85.40 & 9.0 & 1.14 & 3.8 & 1.06 & 0.027 & 39.2 \\
\hline $40-60$ & 4.6 & 4.00 & 93.60 & 9.2 & 1.16 & 2.4 & 0.26 & 0.040 & 6.5 \\
\hline $60-80$ & 5.25 & 10.75 & 84.75 & 9.1 & 1.40 & 2.6 & 0.06 & 0.018 & 3.3 \\
\hline $80-100$ & 7.5 & 3.70 & 90.25 & 9.1 & 1.50 & 3.8 & 0.06 & 0.014 & 4.3 \\
\hline
\end{tabular}

Table 1: Initial characteristics of the soil at the experimental field.

2003 in all plots. Plant emergence began on October 20 and the crop was removed from the field on February 10, 2003. Before that, the experimental field was sometimes cultivated but never irrigated by TWW. An organic spreading of manure was carried out before the plantation at a rate of $40 \mathrm{t} \mathrm{ha}^{-1}$. At the time potato was planted, inorganic nitrogen fertilizer $\left(\mathrm{NH}_{4} \mathrm{NO}_{3}\right)$ was applied at a rate of $200 \mathrm{~kg}$ $\mathrm{ha}^{-1}$. Potato-growing period, October to February, is characterized by rainy winter. Weather data for the crop-growing period were obtained from the nearby weather station; about $100 \mathrm{~m}$ from the experimental plot. The amount of water applied during the experiment, was $84 \mathrm{~m}^{3}$ for each bloc.

\section{Soil sampling and analysis}

An initial soil sampling before the irrigation and a final soil sampling after harvest was performed. Soil samples were collected at three points for each treatment at five depths $(0-20,20-40,40-60,60-80$ and $80-$ $100 \mathrm{~cm}$ ). The samples were then dried, sieved at $2 \mathrm{~mm}$ and analyzed. The particle size was measured by sedimentation (Robinson pipette). The $\mathrm{pH}$ was measured by the electrometric method in distilled water (1:2.5). EC of the soil was determined in an extract of saturated paste. The total calcium carbonate content $(\mathrm{CaCO} 3)$ was measured by acid digestion using a Bernard calcimeter. The soil OC was determined by Wet digestion method [31]. TN was determined by Kjeldahl digestiondistillation method [32]. Extractable $\mathrm{K}_{\text {by }} \mathrm{NH}_{4} \mathrm{OAc}$ [33] and available $\mathrm{P}$ by $0.5 \mathrm{M} \mathrm{NaHCO} 3$ [34]. $\mathrm{NO}_{3}{ }^{-}$was measured by steam distillation in presence of $\mathrm{MgO}$ to remove $\mathrm{NH}_{4}^{+}$and in the presence of both $\mathrm{MgO}$ and Devarda alloy to reduce $\mathrm{NO}_{2}^{-}$and $\mathrm{NO}_{3}^{-}$and to remove the $\mathrm{NH}_{4}^{+}$ obtained.

\section{Water sampling and analysis}

Samples of irrigation water, taken at each irrigation (what suits five samples), were placed in plastic bottles, filtered and stored at low temperature $\left(4^{\circ} \mathrm{C}\right)$. Analyses were performed after four days of storage. $\mathrm{pH}$ and EC were measured directly by $\mathrm{pH}$ meter and salinometer respectively. The determination of cations was performed by Flame Photometry. $\mathrm{PO}_{4}^{3-}$ ions are measured, in an acidic solution with ammonium molybdate, by visible spectrophotometry at the wavelength of $720 \mathrm{~nm}$. Mineral nitrogen was determined by distillation.

\section{Statistical analyses}

Significance of differences in soil properties in response to the effects of kind of water, system of irrigation, and depth were assessed by computing the Analysis of Variance of two or three factors, by the software STATISTICA, Version 5 and a Newman and Keuls test was used to compare the means, considering a significance level of $p<0.05$ throughout the study.

\section{Results and Discussion}

\section{TWW and GW characteristics}

The irrigation water characteristics at the end and the beginning of the study are shown in Table 2 . Both water types were slightly alkaline. The water samples present a variable $\mathrm{pH}$ ranging between 7.2 and 8.6 but which remains acceptable according to the standards of World Health Organization [35] and the Tunisian standard (NT 106.03, 1989) [36]. The EC, ranging between 1.9 and $5 \mathrm{~ms} / \mathrm{cm}$, remain acceptable according the Tunisian Standards (NT 106.03, 1989). However, by Richards diagram (Riverside) [37], the electrical conductivity indicates a high and a very high risk of salinization for TWW and GW respectively, whereas the estimated sodium adsorption ratio (SAR) indicates a low risk of sodification.

The chemical composition of the two kind of irrigation water indicated that $\mathrm{Cl}^{-}, \mathrm{Na}^{+}, \mathrm{Ca}^{2+}$ and $\mathrm{SO}_{4}{ }^{2-}$ were the most abundant cations and anions, respectively. These were followed by bicarbonate $\left(\mathrm{HCO}_{3}{ }^{2}\right.$ ) and $\mathrm{K}^{+}$in descending order according to the concentration levels. Concentrations of these ions show that the water irrigation is strongly mineralized.

For both types of water, the levels of dissolved salts increases with time, which shows an increase in the salinity of which is more important with GW where the values range between 2 and $2.5 \mathrm{~g} / \mathrm{l}$.

TWW characterization revealed that the mean $\mathrm{Cl}$ content is 429.8 $\mathrm{mg} \mathrm{L}^{-1}$ and is lower than reclaimed water irrigation standards $(2000 \mathrm{mg}$ $\left.\mathrm{L}^{-1}\right)$. According to data taken at 2003 from National Office for Sanitation, the suspended solids content is of $20 \mathrm{mg} \mathrm{L}^{-1}$ (Tunisian standards NT $\left.106.03,1989=30 \mathrm{mg} \mathrm{L}^{-1}\right)$. The COD and the BOD concentrations are respectively $91\left(\mathrm{NT}=90 \mathrm{mg} \mathrm{L}^{-1}\right)$ and $14.5 \mathrm{mg} \mathrm{L}^{-1}\left(\mathrm{NT}=30 \mathrm{mg} \mathrm{L}^{-1}\right)$. Thus, the TWW has the characteristics of a relatively high quality effluent.

\section{Soil EC and pH}

At the beginning of the experiment, the $\mathrm{pH}$ was strongly alkaline, values were between 8.7 and 9.2 (Table 3). Values of EC were important in the deep soil layer which could be explained by the accumulation of salts resulted of evaporation and capillary rise. So, GW moves upward from a shallow water table close to the soil surface. The water carries salts which accumulate in the soil as the water is evaporated from the soil surface or transpired through the plants to the atmosphere. These levels will be then the higher limit reached by subsoil waters.

At the end of the study the values of the $\mathrm{EC}$ and $\mathrm{pH}$ decreased significantly in the soil compared to the initial state (Table 3). The reduction of EC value is due to the leaching of salts which is directly related to water movement [38] because crops only remove small amounts of salt. Irrigation water is the main source of adding salts to the soil [39]. In this research the EC values of groundwater and wastewater were significantly similar (Table 2). Therefore, the application of groundwater has caused soil EC statistically equivalent to soil EC caused by wastewater (Table 4). However, mean EC values of wastewater irrigated soil were slightly greater than those of groundwater irrigated soil for the whole layer (Table 3). This result is likely due to the effect of plant uptake on the soil solution. Because wastewater generated higher yield $(286 \mathrm{Kg})$ than groundwater $(260 \mathrm{Kg})$, there was more water uptake and transpiration of Potato due to wastewater irrigation which corroborate the finding of Heidarpour et al. [40].

Whereas, $\mathrm{pH}$ decrease in soil could be due to ammonium 
Page 4 of 7

\begin{tabular}{|c|c|c|c|c|c|c|}
\hline \multirow{2}{*}{ Parameter } & \multicolumn{2}{|c|}{ GW } & \multicolumn{2}{|c|}{ TWW } & \multirow{2}{*}{$N T^{b}$} & \multirow{2}{*}{$\mathrm{WHO}^{\mathrm{C}}$} \\
\hline & Range $^{a}$ & Mean \pm SD & Range & Mean \pm SD & & \\
\hline $\mathrm{pH}$ & $7.4-7.2$ & $7.72 \pm 0.37$ & $7.7-6.9$ & $7.82 \pm 0.55$ & $6.50-8.50$ & $6.5-9.5$ \\
\hline $\mathrm{EC} \mathrm{mS} \mathrm{cm}^{-1}$ & $2.6-5$ & $3.08 \pm 0.97$ & $1.9-3.9$ & $2.36 \pm 0.78$ & 7 & - \\
\hline $\mathrm{RS}\left(\mathrm{g} \mathrm{L}^{-1}\right)$ & $2-2.5$ & $2.20 \pm 0.24$ & $1-2$ & $1.50 \pm 0.45$ & - & - \\
\hline SAR & $6.5-8.1$ & $6.22 \pm 1.38$ & $5-9.9$ & $6.22 \pm 1.95$ & - & - \\
\hline $\mathrm{HCO}_{3}{ }^{2-}\left(\mathrm{mg} \mathrm{L}^{-1}\right)$ & $427-549$ & $402.60 \pm 113.14$ & $305-244$ & $317.20 \pm 59.77$ & - & - \\
\hline $\mathrm{SO}_{4}{ }^{2-}\left(\mathrm{mg} \mathrm{L}^{-1}\right)$ & $345-405$ & $377.60 \pm 19.97$ & $260-345$ & $305.20 \pm 35.20$ & & 500 \\
\hline $\mathrm{Cl}^{-}\left(\mathrm{mg} \mathrm{L}^{-1}\right)$ & $701-445$ & $590.60 \pm 114.63$ & $401-319$ & $429.80 \pm 64.92$ & 2000 & 250 \\
\hline $\mathrm{Ca}^{2+}\left(\mathrm{mg} \mathrm{L}^{-1}\right)$ & $326-213$ & $321.40 \pm 6.56$ & $206-82$ & $192.00 \pm 61.06$ & - & - \\
\hline $\mathrm{Mg}^{2+}\left(\mathrm{mg} \mathrm{L}^{-1}\right)$ & $7-8$ & $8.00 \pm 1.10$ & $6-5$ & $5.80 \pm 0.75$ & - & \\
\hline $\mathrm{Na}^{+}\left(\mathrm{mg} \mathrm{L}^{-1}\right)$ & $434-442$ & $397.20 \pm 71.88$ & $270-341$ & $300.60 \pm 34.35$ & - & - \\
\hline $\mathrm{K}^{+}\left(\mathrm{mg} \mathrm{L}^{-1}\right)$ & $39-46$ & $41.80 \pm 3.06$ & $38-54$ & $41.80 \pm 6.21$ & - & - \\
\hline $\mathrm{NO}_{3}^{-}\left(\mathrm{mg} \mathrm{L}^{-1}\right)$ & $183.5-228.6$ & $193.52 \pm 25.64$ & $22.3-17.3$ & $22.76 \pm 2.89$ & - & 50 \\
\hline $\mathrm{NH}_{4}^{+}\left(\mathrm{mg} \mathrm{L}^{-1}\right)$ & $2.8-10.8$ & $6.74 \pm 0.05$ & $25.2-45.3$ & $24.36 \pm 13.51$ & - & - \\
\hline $\mathrm{P}\left(\mathrm{mg} \mathrm{L}^{-1}\right)$ & $1.53-41.89$ & $18.38 \pm 20.14$ & $1.53-64.31$ & $31.03 \pm 28.42$ & - & - \\
\hline
\end{tabular}

${ }^{a}$ Range indicates (value of initial water sampling - value of final water sampling)

b Tunisian standards [33].

'WHO's drinking water standards 2006

RS: dry residue

SAR: sodium adsorption ratio

Table 2: Characteristics of GW and TWW used for irrigation.

\begin{tabular}{|c|c|c|c|c|c|c|}
\hline \multirow{3}{*}{ Depth (cm) } & \multirow{2}{*}{\multicolumn{2}{|c|}{ (Initial state) }} & \multicolumn{4}{|c|}{ (Final state) } \\
\hline & & & \multicolumn{2}{|c|}{ GW } & \multicolumn{2}{|c|}{ TWW } \\
\hline & $\mathrm{pH}$ & EC & $\mathrm{pH}$ & EC & $\mathrm{pH}$ & EC \\
\hline $0-20$ & 8.70 & 0.9 & 8.52 & 0.77 & 8.45 & 0.78 \\
\hline $20-40$ & 9.00 & 1.14 & 8.44 & 0.61 & 8.58 & 0.67 \\
\hline $40-60$ & 9.20 & 1.16 & 8.93 & 0.7 & 8.56 & 0.84 \\
\hline $60-80$ & 9.14 & 1.4 & 9.01 & 0.67 & 8.79 & 0.74 \\
\hline $80-100$ & 9.20 & 1.5 & 9.06 & 0.65 & 8.85 & 0.82 \\
\hline
\end{tabular}

Table 3: Mean values of $\mathrm{pH}$ and Electrical conductivity $(\mathrm{ms} / \mathrm{cm})$ for the experimental soil under effect of water irrigation

\begin{tabular}{|c|c|c|c|c|c|c|c|c|c|}
\hline \multirow{2}{*}{ Depth (cm) } & \multicolumn{3}{|c|}{ (Initial state) } & \multicolumn{3}{|c|}{ Final state (GW) } & \multicolumn{3}{|c|}{ Final state (TWW) } \\
\hline & OC \% & TN \%o & $\mathrm{C} / \mathrm{N}$ & OC \% & TN \%o & $\mathrm{C} / \mathrm{N}$ & OC \% & TN \%o & $\mathrm{C} / \mathrm{N}$ \\
\hline $0-20$ & 2.14 & 0.38 & 56.3 & 1.87 & 0.67 & 27.9 & 2.02 & 0.63 & 32.06 \\
\hline $20-40$ & 1.06 & 0.27 & 39.2 & 0.8 & 0.38 & 21.0 & 0.52 & 0.23 & 22.6 \\
\hline $40-60$ & 0.26 & 0.4 & 6.5 & 0.5 & 0.26 & 19.2 & 0.32 & 0.2 & 16 \\
\hline $60-80$ & 0.06 & 0.18 & 3.3 & 0.37 & 0.2 & 18.5 & 0.32 & 0.2 & 16 \\
\hline $80-100$ & 0.06 & 0.14 & 4.3 & 0.2 & 0.15 & 13.3 & 0.2 & 0.14 & 14.3 \\
\hline
\end{tabular}

Table 4: Organic characteristic of the soil at the beginning and the end of the study.

nitrification which release free hydrogen ions in the soil, thus lowering the soil $\mathrm{pH}$. This reduction of $\mathrm{pH}$ is slightly important with application of treated wastewater which corroborates the findings of [41-44]. Higher concentrations of ammonium ions in TWW than GW (Table 2) may lead to a higher rate of nitrification releasing free hydrogen ions in the soil, thus lowering more the soil $\mathrm{pH}$. A reduction in soil $\mathrm{pH}$ due to TWW irrigation compared to irrigation by GW has been reported [45-47].

Some investigations showed that the soil irrigation with wastewater increased soil $\mathrm{pH}[48,49]$. Most these investigations described the long term impact of irrigation with sewage and wastewater effluents on soil properties while our study was short term. Soil irrigation with wastewater may cause at first a decrease of soil $\mathrm{pH}$, but after a while it may cause an increase of soil $\mathrm{pH}$.

\section{Soil OC and TN}

Before the irrigation, the content of OC and TN in the soil was most important in surface layers, this is due to the organic amendments (manure) added to the soil before plantation.
After the harvest, results showed that irrigation has significantly reduced $\mathrm{OC}$ and increased $\mathrm{TN}$ of the soil for the first and second soil layer (Table 4), which could be attributed to the mineralization of the organic matter. This mineralization resulted in a reduction of $\mathrm{C} / \mathrm{N}$ ratio and would be supported by the nitrogen added by irrigation. This is in line with findings of Rusan et al. [48] and Khai et al. [50]. Magesan et al. [51] and Ramirez-Fuentes et al. [52] have reported that nutrients supplied by irrigation water stimulate microbial activity in the soil which promotes mineralization of organic matter.

At the end of the study, below $40 \mathrm{~cm}$ depth, the enrichment of the soil by OC might be due to a drive in suspension of the non humified organic particles towards the deeper layer which resulted in an significant increase in the percentages of $\mathrm{OC}$ and a significant rise in $\mathrm{C} / \mathrm{N}$ ratio (Table 4 ).

\section{Phosphorus}

The initial and final soil $\mathrm{P}_{2} \mathrm{O}_{5}$ concentration decreased significantly from the top of the soil to the deeper layers. Below $20 \mathrm{~cm}$, there was no significant difference in $\mathrm{P}_{2} \mathrm{O}_{5}$ concentration in the soil (Table 5). The 
accumulation of $\mathrm{P}_{2} \mathrm{O}_{5}$ in the first soil layer could be due to application of NPK fertilizer and the irrigation effect. Furthermore, the reduction of $\mathrm{P}_{2} 0_{5}$ contents in the surface layer at the end of the study could be due to the plant uptake and especially to the leaching of this element which resulted in the enrichment of the groundwater by the phosphor (Table 2). In $20 \mathrm{~cm}$ soil depth, the concentration of $\mathrm{P}_{2} \mathrm{O}_{5}$ was significantly higher with GW irrigated soil (Table 5).This result is similar to those of other researchers $[40,53-55]$. The soil $\mathrm{P}_{2} 0_{5}$ concentration was unaffected by irrigation method (Table 6).

\section{Potassium}

Based on analysis of variance, the high content of $\mathrm{K}$ in the surface layer (Table 7) at the beginning of study is due to the application of NPK fertilizers.

At the end of the study, the soil K content decreased significantly in the $0-40 \mathrm{~cm}$ layer and increased significantly below $40 \mathrm{~cm}$ depth (Table 7). This result showed the importance of this nutrient leaching in the studied soil.

In the plot irrigated by the $\mathrm{GW}$, irrigation system effect is observed in 0-20, 20-40 and 60-80 cm soil depth (Table 8). Indeed, the accumulation of $\mathrm{K}$ in the soil is less large with the IG which probably attests the efficiency of absorption of $\mathrm{K}$ with this system of irrigation. In another manner absorption of $\mathrm{K}$ is larger by using the IG.

In the plot irrigated by the TWW, irrigation system effect is observed only in $0-20 \mathrm{~cm}$ soil depth (Table 8). Contrary to the case of the $\mathrm{GW}$, it is with the IG that the accumulation of the $\mathrm{K}$ in the soil is the most important. This can be related to the difference in movement of this nutriment with the tow techniques of irrigation.

\section{Nitrate}

At the beginning of the study, soil $\mathrm{NO}_{3}{ }^{-}$content was significantly greater in surface layers, which corroborate the finding of Feng et al. [56]. The higher $\mathrm{NO}_{3}{ }^{-}$content in the upper layer might be attributed to the application of NPK fertilizers.

\begin{tabular}{|c|c|c|c|c|}
\hline \multirow{2}{*}{ Depth $(\mathrm{cm})$} & \multicolumn{2}{|c|}{ Beginning of the study } & \multicolumn{2}{c|}{ End of the study } \\
\cline { 2 - 5 } & GW & TWW & GW & TWW \\
\hline $0-20$ & $170.00 \mathrm{~A}$ & $127.00 \mathrm{a}$ & $93.50 \mathrm{a}^{*}$ & $80.25 \mathrm{a}^{*}$ \\
\hline $20-40$ & $42.00 \mathrm{~B}^{*}$ & $55.67 \mathrm{~b}^{*}$ & $34.00 \mathrm{~b}^{*}$ & $39.00 \mathrm{~b}^{*}$ \\
\hline $40-60$ & $28.67 \mathrm{~b}^{*}$ & $25.67 \mathrm{~b}^{*}$ & $23.00 \mathrm{~b}^{*}$ & $30.75 \mathrm{~b}^{*}$ \\
\hline $60-80$ & $24.33 \mathrm{~b}$ & $62.00 \mathrm{~b}$ & $29.75 \mathrm{~b}^{*}$ & $25.75 \mathrm{~b}^{*}$ \\
\hline $80-100$ & $23.67 \mathrm{~b}^{*}$ & $26.33 \mathrm{~b}^{*}$ & $31.50 \mathrm{~b}^{*}$ & $24.25 \mathrm{~b}^{*}$ \\
\hline
\end{tabular}

Data in the same column followed by the same letter $(a, c)$ were not significantly different at the $P<0.05$ level (Test of Newman-Keuls) and $\left(^{*}\right.$ ) indicates that there is no significant difference $(P<0.05)$ between $\mathrm{GW}$ and TWW soils.

Table 5: Means of $\mathrm{P}_{2} \mathrm{O}_{5}\left(\mathrm{mg} \mathrm{kg}^{-1}\right)$ for each soil layer at the beginning and the end of the study.

\begin{tabular}{|c|c|c|c|c|}
\hline \multirow{2}{*}{ Depth (cm) } & \multicolumn{2}{|c|}{ S } & \multicolumn{2}{c|}{ IG } \\
\cline { 2 - 5 } & GW & TWW & GW & TWW \\
\hline $0-20$ & $176.40 \mathrm{a}$ & $139.80 \mathrm{a}$ & $111.20 \mathrm{a}$ & $149.00 \mathrm{a}$ \\
\hline $20-40$ & $51.40 \mathrm{a}$ & $56.40 \mathrm{a}$ & $38.00 \mathrm{a}$ & $45.40 \mathrm{a}$ \\
\hline $40-60$ & $28.40 \mathrm{a}$ & $29.80 \mathrm{a}$ & $57.80 \mathrm{a}$ & $26.00 \mathrm{a}$ \\
\hline $60-80$ & $39.40 \mathrm{a}$ & $31.20 \mathrm{a}$ & $30.40 \mathrm{a}$ & $39.20 \mathrm{a}$ \\
\hline $80-100$ & $45.00 \mathrm{a}$ & $40.96 \mathrm{a}$ & $26.40 \mathrm{a}$ & $40.46 \mathrm{a}$ \\
\hline
\end{tabular}

Values in any column followed by the same letter do not differ at the 0.05 significance level (Test of Newman-Keuls).

Table 6: Means of $\mathrm{P}_{2} \mathrm{O}_{5}\left(\mathrm{mg} \mathrm{kg}^{-1}\right)$ for the experimental soil under effect of irrigation system.

\begin{tabular}{|c|c|c|c|c|}
\hline \multirow{2}{*}{ Depth (cm) } & \multicolumn{2}{|c|}{ Begining of the study } & \multicolumn{2}{c|}{ End of the study } \\
\cline { 2 - 5 } & GW & TWW & GW & TWW \\
\hline $0-20$ & $270 a^{*}$ & $260 a^{*}$ & $170 a^{*}$ & $170 a^{*}$ \\
\hline $20-40$ & $220 a b^{*}$ & $230 a^{*}$ & $200 a$ & $160 a$ \\
\hline $40-60$ & $160 b^{*}$ & $160 b^{*}$ & $190 a$ & $150 a$ \\
\hline $60-80$ & $90 c^{*}$ & $90 c^{*}$ & $160 a$ & $120 a$ \\
\hline $80-100$ & $70 c^{*}$ & $70 c^{*}$ & $130 a$ & $60 b$ \\
\hline
\end{tabular}

Data in the same column followed by the same letter $(a, c)$ were not significantly different at the $P<0.05$ level (Test of Newman-Keuls), and $\left({ }^{*}\right)$ indicates that there is no significant difference $(P<0.05)$ between GW soil and TWW soil.

Table 7: Means of $\mathrm{K}\left(\mathrm{mg} \mathrm{kg}^{-1}\right)$ for each soil layer at the beginning and the end of the study.

\begin{tabular}{|c|c|c|c|c|}
\hline \multirow{2}{*}{ Depth (cm) } & \multicolumn{2}{|c|}{ S } & \multicolumn{2}{|c|}{ IG } \\
\cline { 2 - 5 } & GW & TWW & GW & TWW \\
\hline $0-20$ & $260 a$ & $220 a b$ & $150 b$ & $290 b$ \\
\hline $20-40$ & $210 b c$ & $210 a$ & $160 c$ & $240 a$ \\
\hline $40-60$ & $160 a$ & $150 a$ & $170 a$ & $160 a$ \\
\hline $60-80$ & $190 b$ & $110 a$ & $080 a$ & $120 a$ \\
\hline $80-100$ & $110 a$ & $120 a$ & $110 a$ & $110 a$ \\
\hline
\end{tabular}

Data in the same column followed by the same letter $(a, c)$ were not significantly different at the $\mathrm{P}<0.05$ level (Test of Newman-Keuls)

Table 8: Mean value of $\mathrm{K}\left(\mathrm{mg} \mathrm{kg}^{-1}\right)$ in the experimental soil under effect of the irrigation system.

After the irrigation, the $\mathrm{NO}_{3}^{-}$distribution pattern throughout the soil profile was significantly changed (Table 9). The lowest $\mathbf{N O}_{3}$ content was found in $20-40 \mathrm{~cm}$ depth in all plot types. $\mathrm{NO}_{3}^{-}$content then increased with depth, reaching maximum levels at $40-60 \mathrm{~cm}$.

Even though the $\mathrm{NO}_{3}{ }^{-}$content in the upper layers (40 cm deep) was generally found to be lower after the irrigation than before, there were differences in the distribution pattern throughout the soil profile in the different plot types. In TWW irrigated soil, the $\mathrm{NO}_{3}{ }^{-}$content in all layers was generally lower after the irrigation, whereas in GW irrigated soil, the $\mathrm{NO}_{3}$ - content in the 40-60 cm layers was slightly higher than before irrigation, suggesting that $\mathrm{NO}_{3}^{-}$had accumulated in deeper soil layers due to the irrigation.

Like the case of $\mathrm{P}_{2} \mathrm{O}_{5}$, the soil $\mathrm{NO}_{3}$ - concentration was unaffected by irrigation method (Table 10).

\section{Impact on groundwater}

The $\mathrm{NO}_{3}$ - content of the GW increased from 183.5 before to 228.6 $\mathrm{mg} / \mathrm{l}$ after the irrigation (Table 2 ), thereby exceeding the drinking water standard of the World Health Organization of $50 \mathrm{mg} \mathrm{L}^{-1}$ [9].

The leaching of soil $\mathrm{NO}_{3}^{-}$from the plant root zone to the groundwater is mainly determined by the high amount of $\mathrm{NO}_{3}^{-}$(large amounts of water and $\mathrm{N}$ fertilizer) accumulated in the soil profile exceeding the requirements of the cultivated plants [57] in conjunction with or followed by the high drainage volume $[58,59]$ accentuated by the sandy textured soil and the high amount of rainfall and irrigation (Figure 2).

According to the international drinking water standards the phosphorus content reaching $41.85 \mathrm{mg} \mathrm{L}^{-1}$ after irrigation exceed the limit of potability $\left(0,5 \mathrm{mg} \mathrm{L}^{-1}\right)$ which can contribute to Algal growth and eutrophication [60].

The $\mathrm{pH}$ of the groundwater was decreased by the irrigation from 7.4 to 7.2 , and the EC was increased from 2.6 to $5 \mathrm{mS} \mathrm{cm}^{-1}$ (Table 2), indicating a higher concentration of dissolved salts in the groundwater which join the results of Feng et al. [56] and Kallel and Bouzid [61]. In 
Citation: Jemai I, Ben Aissa N, Gallali T, Chenini F (2013) Effects of Municipal Reclaimed Wastewater Irrigation on Organic and Inorganic Composition of Soil and Groundwater in Souhil Wadi Area (Nabeul, Tunisia). Hydrol Current Res 4: 160. doi:10.4172/2157-7587.1000160

\begin{tabular}{|c|c|c|c|c|}
\hline \multirow{2}{*}{ Depth $(\mathrm{cm})$} & \multicolumn{2}{|c|}{ Begining of the study } & \multicolumn{2}{c|}{ End of the study } \\
\cline { 2 - 5 } & GW & TWW & GW & TWW \\
\hline $0-20$ & $70.14 \mathrm{~A}^{*}$ & $81.67 \mathrm{a}^{*}$ & $48.05 \mathrm{a}^{*}$ & $36.75 \mathrm{a}^{*}$ \\
\hline $20-40$ & $85.35 \mathrm{~A}^{*}$ & $67.75 \mathrm{a}^{*}$ & $40.15 \mathrm{a}^{*}$ & $32.42 \mathrm{a}^{*}$ \\
\hline $40-60$ & $51.05 \mathrm{a}^{*}$ & $54.57 \mathrm{a}^{*}$ & $59.57 \mathrm{a}^{*}$ & $41.79 \mathrm{a}^{*}$ \\
\hline $60-80$ & $64.87 \mathrm{a}^{*}$ & $81.78 \mathrm{a}^{*}$ & $55.05 \mathrm{a}^{*}$ & $36.12 \mathrm{a}^{*}$ \\
\hline $80-100$ & $56.04 \mathrm{a}^{*}$ & $63.27 \mathrm{a}^{*}$ & $53.89 \mathrm{a}^{*}$ & $35.65 \mathrm{a}^{*}$ \\
\hline
\end{tabular}

Data in the same column followed by the same letter $(a, c)$ were not significantly different at the $\mathrm{P}<0.05$ level, and $\left({ }^{*}\right)$ indicates that there is no significant difference $(P<0.05)$ between GW soil and TWW soil.

Table 9: Means of $\mathrm{NO}_{3}^{-}\left(\mathrm{mg} \mathrm{kg}^{-1}\right)$ for each soil layer at the beginning and the end of the study.

\begin{tabular}{|c|c|c|c|c|}
\hline \multirow{2}{*}{ Depth (cm) } & \multicolumn{2}{|c|}{ S } & \multicolumn{2}{c|}{ IG } \\
\cline { 2 - 5 } & GW & TWW & GW & TWW \\
\hline $0-20$ & $37.69 a$ & $45.10 a$ & $42.20 a$ & $39.59 a$ \\
\hline $20-40$ & $46.92 a$ & $37.34 a$ & $51.29 a$ & $36.18 a$ \\
\hline $40-60$ & $49.18 a$ & $48.59 a$ & $38.43 a$ & $41.38 a$ \\
\hline $60-80$ & $44.92 a$ & $43.92 a$ & $43.53 a$ & $35.16 a$ \\
\hline $80-100$ & $48.58 a$ & $40.90 a$ & $42.99 a$ & $40.46 a$ \\
\hline
\end{tabular}

Values in any column followed by the same letter do not differ at the 0.05 significance level (Test of Newman-Keuls).

Table 10: Mean value of $\mathrm{NO}_{3}^{-}\left(\mathrm{mg} \mathrm{kg}^{-1}\right)$ in the experimental soil under effect of the irrigation system.

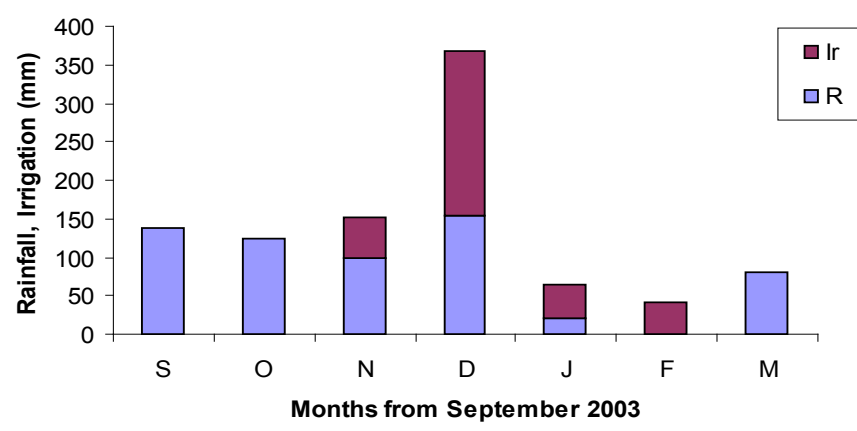

Figure 2: Monthly distribution of rainfall and irrigation depth during the simulation period for the period of September to March.

Sokra perimeter of the side of Tunis, Zekri et al. [62] have observed an increase in GW salinity from 2.3 to $4 \mathrm{~ms} \mathrm{~cm}^{-1}$ after 20 years of irrigation with TWW.

\section{Conclusion}

These results show that after a partner of irrigation, the evolution of chemical constituents in soil layers was not influenced by the kind of irrigation water. However, it was influenced by water movement patterns, chemical concentrations in irrigation water and plant uptake. The most important concern was the leaching of salts, phosphorus and nitrate to the GW leading to the degradation of its geochemical quality. Therefore, the impact of TWW irrigation on soil composition was not apparent in this experiment but it was strongly significant on GW quality.

\section{Acknowledgement}

The authors are grateful to the INRGREF institute for providing financial support for this work. El Haddi El Hamrouni and Leila Ben Dhiaa are also thanked for their great help and assistance with laboratory work.

\section{References}

1. MEDD (2005) Rapport National sur l'Etat de l'Environnement 31-40.
2. Bahri A (1998) Wastewater reclamation and reuse in Tunisia, In: Wastewater Reclamation and Reuse, Water Quality Management Library. Technomic Publishing Co 10: 877-916.

3. Brissaud $F(2008)$ Criteria for water recycling and reuse in the Mediterranean countries. Desalination $218: 24-33$.

4. Qadir M, Wichelns D, Raschid-Sally L, McCornick PG, Drechsel P, et al. (2010) The challenges of wastewater irrigation in developing countries. Agricultural Water Management 97: 561-568.

5. UNDP (1987) Reclaimed water reuse in agriculture", Technical Report (in French), Vol. 1, 3rd Part, 69 p.+ annexes, Project RAB/80/011, Water Resources in the North African Countries, Rural Engineering Research Centre (Tunisia) - United Nations Development Program, May 1987.

6. Jimenez-Cisneros B (1995) Wastewater reuse to increase soil productivity. J Water Sci Technol 32: 173-180.

7. NRC (1996) Use of reclaimed water and sludge in food production. Washington D.C: National Academy Press 70.

8. Candela L, Fabregat S, Josa A, Suriol J, Vigués N, et al. (2007) Assessment of soil a groundwater impacts by treated urban wastewater reuse. A case study: application in a golf course (Girona, Spain). Sci Total Environ 374: 26-35.

9. WHO (2006) Guidelines for the Safe Use of Wastewater, Excreta and Grey Water. Wastewater Use in Agriculture. Geneva 2.

10. Jedidi N, Hassen A (1991) Propriétés physiques des sols et pouvoir colmatant des eaux usées en fonction de leur degré de traitement. Cah Orstom Pédol 1: 3-10.

11. Gloaguen T, Forti MC, Lucas Y, Montes CR, Gonçalves RAB et al. (2007) Soil solution chemistry of a Brazilian Oxisol irrigated with treated sewage effluent. Agricultural water management 88: 119-131.

12. Chenini F, Trad M, Réjeb S, Chaabouni Z, Xanthoulis D (2002) Optimisation et durabilité du traitement et de l'utilisation des eaux usées en agriculture. Projet Inco 31-35.

13. Ndiaye ML, Guèye GA, Pfeifer HR (2006) Impacts des eaux usées sur l'évolution microbiologique des sols : étude de cas à Pikine Dakar-Sénégal. Agrosolutions $17: 1$.

14. Vazquez-montiel O, Horan NJ, Mara DD (1996) Management of domestic waste water for reuse in irrigation. Water Sci Technol 33: 355-362.

15. Muñoz I, Gómez-Ramos MJ, Agüera A, García-Reyes JF, Molina-Díaz A, et al. (2009) Chemical evaluation of contaminants in wastewater effluents and the environmental risk of reusing effluents in agriculture. Trends Anal Chem 28: $676-694$

16. Oppel J, Broll G, Löffler D, Meller M, Römbke J, et al. (2004) Leaching behaviour of pharmaceuticals in soil-testing-systems: a part of an environmental risk assessment for groundwater protection. Sci Total Environ 328: 265-273.

17. Toribio M, Romanyà $\mathrm{J}$ (2006) Leaching of heavy metals ( $\mathrm{Cu}, \mathrm{Ni}$ and $\mathrm{Zn}$ ) and organic matterafter sewage sludge application to Mediterranean forest soils. Sci Total Environ 363: 11-21.

18. Weber S, Khan S, Hollender J (2006) Human risk assessment of organic contaminants in reclaimed wastewater used for irrigation. Desalination 187: 53-64.

19. Khan S, Cao Q, Zheng YM, Huang YZ, Zhu YG (2008) Health risks of heavy metals in contaminated soils and food crops irrigated with wastewater in Beijing, China. Water Res 152: 686-692.

20. Li P, Wang X, Allinson G, Li X, Xiong X (2009) Risk assessment of heavy metals in soil previously irrigated with industrial wastewater in Shenyang, China. J Hazard Mater 161: 516-521.

21. Yu L, Fink G, Wintgens Th, Melin Th, Ternes Th (2009) Sorption behavior of potential organic wastewater indicators with soils. Water Res 43: 951-960.

22. Jnad I, Lesikar B, Kenimer A, Sabbagh G (2001) Subsurface drip dispersal of residencial effluent. I: Soil chemical characteristics. Trans Am Soc Agric Eng 44: 1149-1157.

23. Hayes AR, Mancino CF, Pepper IL (1990) Irrigation of turfgrass with secondary sewage effluent. I: Soil and leachate water quality. Agron J 82: 938-943.

24. Mancino C, Pepper IL (1992) Irrigation of turfgrass with secondary effluent, soil quality. Agron J 8: 650-654 
Citation: Jemai I, Ben Aissa N, Gallali T, Chenini F (2013) Effects of Municipal Reclaimed Wastewater Irrigation on Organic and Inorganic Composition of Soil and Groundwater in Souhil Wadi Area (Nabeul, Tunisia). Hydrol Current Res 4: 160. doi:10.4172/2157-7587.1000160

25. Mahjoub O, Leclercq M, Bachelot M, Casellas C, Escande A, et al. (2009) Estrogen, aryl hysdrocarbon and pregnane $X$ receptors activities in reclaimed water and irrigated soils in Oued Souhil area (Nabeul, Tunisia). Desalination 246: 425-434.

26. Rekaya M (1986) Experimentation pilote de recharge artificielle à partir des eaux usées traitées. Cas de la nappe de l'Oued Souhil (Nabeul).

27. Plata Bedmar A, Rekaya M (1987) Application des techniques nucléaires aux études de recharge artificielle d'un aquifère côtier en Tunisie.

28. Kallali H, Yoshida M (2002) Soil and subsoil characterization of Souhil Wadi (Nabeul) pilot plant for wastewater infiltration-percolation, in: Proc. International Symposium on Environmental Pollution Control and Waste Management (EPCOWM'2002), Tunis, Tunisia.

29. DGGREE (2001) Périmètres irrigués à partir des eaux usées traitées.

30. Kallali H, Anane M, Jellali S, Tarhouni J (2007) GIS-based multi-criteria analysis for potential wastewater aquifer recharge sites. Desalination 215: 111-119.

31. Walkley A, Black CA (1934) An examination of the Degtjareff method for determining soil organic matter and a proposal modification of the chromic acid titration method. Soil Science 37: 29-38.

32. Bremner JM (1960) Determination of nitrogen in soil by the Kjeldahl method. $J$ Agrie Sc 55: 11-33

33. Thomas GW (1982) Exchangeable cations. In: Methods of soil Analysis. (Page AL, Miller RH and Keeney DR, 2nd eds)(Madison). Agronomy 9: 154-157.

34. Olsen SR, Cole CV, Watanabe FS, Dean LA (1954) Estimation of available phosphorus in soils by extraction with sodium bicarbonate. US Department of Agriculture Circular 939. US Government Printing Office, Washington DC, USA. 19.

35. WHO (2006) Guidelines for the Safe Use of Wastewater, Excreta and Grey Water. Wastewater Use in Agriculture. Geneva 2.

36. INNORPI (1989) Environment Protection - Use of reclaimed water for agricultural purposes - Physical, chemical and biological specifications (in French), Tunisian standards, INSTITUT NATIONAL DE LA NORMALISATION ET DE LA PROPRIETE INDUSTRIELLE, NT 106.03

37. US Salinity Laboratory Staff (1954) Diagnosis and improvement of saline and alkali soils, US Department of Agriculture, Handbook $n^{\circ} 60$, Washington DC.

38. Nakayama FS, Bucks DA (1986) Trickle Irrigation for Crop Production: Design, Operation and Management. Elsevier, New York, NY

39. Hussain Gh, Al-Saati AJ (1999) Wastewater quality and its reuse in agriculture in Saudi Arabia. Desalination 123: 241-251.

40. Heidarpour M, Mostafazadeh-Fard B, Abedi Koupai J, Malekian R (2007) The effects of treated wastewater on soil chemical properties using subsurface and surface irrigation methods. Agricultural water management 90: 87-94.

41. Yadav RK, Goyal B, Sharma RK, Dubey SK, Minhas PS (2002) Post-irrigation impact of domestic sewage effluent on composition of soils, crops and groundwater-A case study. Environmental International 28: 481-486.

42. Abbas ST, Sarfraz M, Mehdi SM, Hassan G, Obaid-Ur-Rehman (2007) Trace elements accumulation in soil and rice plants irrigated with the contaminated water. Soil \& Tillage Research 94: 503-509.

43. Solis C, Andrade E, Mireles A, Reyes-Solis IE, Garcia-Calderon N, et al. (2005) Distribution of heavy metals in plants cultivated with wastewater irrigated soils during different periods of time. Nuclear Instruments and Methods in Physics Research B 241: 351-355.

44. Herpin U, Gloaguen TV, Fonseca AF, Montes CR, Mendonça FC, et al. (2007)
Chemical effects on the soil-plant system in a secondary treated wastewater irrigated coffee plantation-A pilot field study in Brazil. Agricultural Water Management 89: 105-115.

45. Mohammad MJ, Mazahreh N (2003) Changes in soil fertility parameters in response to irrigation of forage crops with secondary treated waste water. Commun Soil Sci Plant Anal 34: 1281-1294.

46. Mojiri A (2011) Effects of Municipal Wastewater on Physical and Chemical Properties of Saline Soil. J boil Environ Sci 5: 71-76.

47. Singh A, Agrawal M (2012) Effects of Waste Water Irrigation on Physical and Biochemical Characteristics of Soil and Metal Partitioning in Beta vulgaris. L Agric Res 1: 379-391.

48. Rusan M, Hinnawi S, Rousan L (2007) Long term effect soil and plant quality parameters. Desalination 215: 143-152.

49. Rattan RK, Datta SP, Chhonkar PK, Suribabu K, Singh AK (2005) Long-term impact of irrigation with sewage effluents on heavy metal content in soils, crops and groundwater-a case study. Agriculture, Ecosystems and Environment 109 310-322.

50. Khai NM, Tuan PT, Vinh CN, Oborn I (2008) Effects of using wastewater as nutrient sources on soil chemical properties in peri-urban agricultural systems. VNU Journal of Science Earth Sciences 24: 87-95.

51. Magesan GN, Williamson JC, Yeates GW, Lloyd-Jones ARH (2000) Wastewater C:N Ratio Effects on Soil Hydraulic Conductivity and Potential Mechanisms for Recovery. Bioresource Technology 71: 21-27.

52. Ramirez-Fuentes E, Lucho-Constantino C, Escamilla-Silva E, Dendooven L (2002) Characteristics, and carbon and nitrogen dynamics in soil irrigated with wastewater for different lengths of time. Bioresource Technology 85 : 179-187.

53. Reddy KR, Overcash MR, Khaleel R, Westerman PW (1980) Phosphorous adsorption-desorption characteristics of two soil utilized for disposal of animal wastes. J Environ Qual 9: 86-92.

54. Liu F, Mitchel CC, Odom JW, Hill DT, Rochester EW (1998) Effects of swine lagoon effluent application on chemical properties of a loamy sand. Gioresour. Technol 63: 54-73.

55. Midrar UH, Khattak RA, Puno HKh, Saleem-Saif M (2004) NPK status in effluent irrigated soils of some selected sites of NWFP. Int J Agric Biol 6: 264-267.

56. Feng ZZ, Wang XK, Feng ZW (2005) Soil N and salinity leaching after the autumn irrigation and its impact on groundwater in Hetao Irrigation District, China. Agricultural Water Management 71: 31-143.

57. Fatta-Kassinos D, Kalavrouziotis IK, Koukoulakis PH, Vasquez MI (2011) The risks associated with wastewater reuse and xenobiotics in the agroecological environment. Science of The Total Environment 409: 3555-3563.

58. Di HJ, Cameron KC (2002) Nitrate leaching in temperate agroecosystems: sources, factors and mitigating strategies. Nutr Cycl Agroecosyst $46: 237-256$

59. Ottman MJ, Tickes BR, Husman SH (2000) Nitrogen-15 and bromide tracers of nitrogen fertilizer movement in irrigated wheat production. J Environ Qual 29: $1500-1508$.

60. Lazarova V, Bahri A (2005) Water Reuse for Irrigation: Agriculture, Landscapes, and Turf Grass. CRC Press, Boca Raton, USA.

61. Kallel M, Bouzid J (2002) Impact de la réutilisation des eaux usées traitées sur la qualité des eaux souterraines et sur le sol: cas de la région de sfax. WATMED, 10-13 Octobre 2002, Monastir, Tunisie.

62. Zekri S, Ghezal L, Aloui T, Djebbi K (1997) Les externalités négatives de l'utilisation des eaux usées traitées en agriculture; Options Méditerranéennes, Série.
This article was originally published in a special issue, Water Conservation Technology handled by Editor(s). Prof. Berrin Tansel, Florida International University, USA 